\title{
The Anthropocene and the [SARS-CoV-2] Contagion: A Study on the Virological Metaphors of Jacques Derrida and the Contamination of the Ontological Body
}

Arindam Nandi

Research Scholar, University of Calcutta, Calcutta, India.

"This supernatural soliciting cannot be ill, cannot be good" -William Shakespeare, Macbeth

"Evil resides in the very gaze which perceives Evil all around itself" -Georg Wilhelm Friedrich Hegel

The Severe Acute Respiratory Syndrome Coronavirus 2, or the SARS-CoV- $2^{1}$ that is upon the world body at the current moment in time is much less of a physiological [both with respect to human or animal biology] aberration or a pathological malady than an(other) indication, an(other) anticipatory marker if we may, of an emerging epochal ontology ${ }^{2}$ that presupposes if not accompanies the Anthropocene ${ }^{3}$. This ontology that we currently see [or are not able to see] and talk about is a different kind of ontology and a new study of being [one that has already been explained at length by the likes of Jean Baudrillard (Simulacra and Simulation), Jean Francois Lyotard (The Postmodern Condition) and Jacques Derrida], not necessarily with respect to the effect it has or is going to have on global geopolitics, but rather with respect to how this kind of being should be perceived and received, along with the knowledge, understanding and dimension that it espouses. This ontology would be called the ontology of the virus, or a 'virology $y^{4}$.

So what does this virology [or more specifically this anthropological virology] entail? What are its grounding mechanics and metaphysical presuppositions? And how is this virological ontology connected to what we call the arrival of the Anthropocene? To answer this series of questions, we must begin by looking back about seventy years into the past, at a time when the phenomenological project of Edmund Husser $1^{5}$ [and to an extent Martin Heidegger] and his ideas of 'being' and 'self-presence' were being abandoned and substituted [albeit in a manner that wouldn't be exposed till the next ten to fifteen years] by Jacques Derrida and his quasi-metaphysical non-ideas of absence, trace, arche-writing, the supplement, the pharmakon, etc 6 . Why this substitution in the discourse of philosophy is important to our investigation is a simple enough matter to comprehend: unlike the Western cogito, the phenomenological subject or the Freudian ego, the being of the virus lacks the immediacy of any self-presence. That is, a virus or a contagion does not present itself in its immediacy and only does so through the body of the host it infects and infests. A virus, therefore, is pure trace. 
This shift ${ }^{7}$, from the ontology of the body of the subject that is present, to the latency of the virus can be explored through a series of rhetorical analogies: the overt and the covert, the visible and the invisible, the manifest and the latent, and essence and movement, among many others. It is this paradigmatic shift in the thinking of being as that which absents itself, makes itself invisible, instead of remaining visible to the anthropological eye that sets the mise-en-scène of both contemporary global culture and the philosophic-political transformation that has been under process since the onset of French poststructuralism. The virus, therefore, can be said to indicate the coming of a being 'after being' [as selfpresence]. Moving on to the next enquiry at hand, the question of grounding principles is a paradoxical one, given the nature of the virus as a Derridean contagion. The very nature of virology and hence the non-essential state of being of a virus makes it impossible to determine for it a singular framework or point of origin. We will come back to the origin point of a virus later on in the essay, but for now, we will focus on the provisional or contingent qualities or tendencies of a contagion. Derrida has fully formulated a 'metaphysics of contamination ${ }^{8}$ ' which over-determines the ontological state of this contagion. Christina Howells in her book Deconstruction from Phenomenology to Ethics explains this law of 'supplementarity' and 'originary impurity' [delineated originally by Derrida in Voice and Phenomenon: Introduction to the Problem of the Sign in Husserl's Phenomenology] that distinguishes Derrida's quest for this new metaphysics of virology from Husserl's phenomenology of presence:

The additional or 'supplementary' features are in fact nothing of the sort, they are essential to the very constitution that they have been deemed to contaminate. Truth and subjectivity do not exist in a realm prior to language, they depend on language for their very existence. Husserl's desire to preserve the immediacy of presence has been thwarted by the logic of his own arguments: there is no original presence, only representation; no direct intuition, only mediated knowledge; no pure present moment, only contamination of past and future; no self-identity, only irremediable self-division, and difference (Howells 38)

The supplement or the contagion therefore in Derrida is indistinguishable from the thing that it contaminates, a deduction which further insinuates two implications: the metaphor of contamination plays around with the dividing line ${ }^{9}$ between the body/virus dialectic making the binary 'porous and highly permeable', subsequently also implying the 'interpenetration' of the two apparently separate elements of the body/contagion dialectic. That is, apart from the virus exhibiting an ontology or being, this interpenetration also complies with the presence of a virus-like potential of the body itself, a potential that Derrida would further explore in his studies of auto-immunology ${ }^{10}$ as another epidemiological metaphor [autoimmunity as the proclivity of body's immune system to attack its own cells and tissues; whereby the body commits to internal self-sabotage].

We will return to the body/contagion dialectic later on in the essay, but now we will shift our attention back to understanding the functional nature of the virus or the contagion itself. As we have already mentioned, 'the virus is pure trace'. So then what does this trace-like quality engender or necessitate? It engenders absence and necessitates a trail or the action of trailing. Not that it never presents itself as such, but it never does so in its purest state, but only through the connected body of the infected host. It makes itself visible to the scientist, the doctor, the one undertaking the trail only fractionally through the bodies that carry it or exhibit its symptoms. But this fraction is less than a marginal one. And this is the success of the virus as a pure trace and the inefficacy of any state-imposed quarantine. Only the body is isolated, kept locked down, unhinged from social connectivity, but the spaces that separate these bodies, the spaces of the in-between, the deserted and isolated spaces are the ones that harbor the virus in its invisible form, in its trance-like nature. Space is both the living matrix and the dying ground of a contagion. The contagion spreads itself though space but dies when exposed to space without hosts. Because contrary to the assumptions of the epidemiologist, the body doesn't inhibit the virus, the body, in 
fact, is the endpoint of the virus. Kept in isolation, the virus dies, and the body is recovered. But where it roams about in absolute independence is in the aerial and territorial topography traced by the infected bodies before they had been isolated and quarantined by the state or the police. This trace is never noticed, and even after the virus dies this trace is never trailed or isolated or kept under vigilant surveillance, like the body [both infected and cured] is. Empty space has no value to the powers of the state. Because here is where the virus does not present itself [the state is a slave to human presence], it keeps itself absent and invisible, making it seem falsely redundant, and hence heavily effective. The virus is not (in) the body [inside the body the virus is always a mutating multiplicity]. It is not a point in space. It is not present. It is always in the between, as an invisible and forever absent trace. The virus is space.

How does this virological turn in the study of ontology indicate a conflation with the Anthropocene? Or in other words, how does the study of disease (as that which supposedly attacks the human body) anticipate the coming of a purely human socio-political universe? Viral or Bacterial Epidemics are not modern phenomena. Epidemics and even pandemics have been an integral part of human history. The Bubonic Plague [caused by the Yersinia pestis bacteria] which affected the Byzantine empire and the Mediterranean cities in the years 541-42 claimed over 25 million lives in the Plague of Justinian, and then again close to 185 million the time it recurred as The Black Death in the middle for the fourteenth century, ravaging parts of Europe, Africa, and Asia. In the last 150 years cholera has hit twice $(1852,1910)$ resulting in a pandemic each time and killing close to 2 million, and the pandemic-causing influenza flu has rioted over the world thrice $(1889,1918,1956)$ claiming more than 50 million casualties. But to use virology or the virus as a metaphor, one must look beyond the pathological sense of the term and its epidemiological significance to a more cultural, political, and socioeconomic mode of signification. The highly stratified functioning of the liberal democracy, the flow of capital inside the world market, the convoluted and intricate latency of global bureaucracies, the cold war, information technology, and computerization, diplomacy and negotiation over raw power and force, the collapse of Communism in 1991, and finally the rise of the world wide web [and everything it entails: social media, networking, memetics, crypto-currency], all point to a common underlying operation through which power, information, knowledge, agency, and news are constantly being transmitted without either a central point of origin or an effective end [neither arche, nor telos]. Operation through the viral agency. These man-made institutions or systems or discourses that have previously submerged the whole of the visible symbolic world have now lost all centrality to the human subject, and have turned their focus instead on space, movement and flow. The Anthropocene hence [always] follows the function of the virus.

Much like the supplement, the virus adds itself to the thing (which in this case is the human host) and becomes a part of it. Viruses, once they attain the status of a pandemic aren't eradicated, they are controlled. A vaccine doesn't ensure non-infection, it ensures that the immune system of the corrupted body is strong enough to resist and fight against the power of the contagion/supplement [protection not elimination]. The virus always adds itself to the body, either as death [indicating a victory of the virus through supplantation] or through a constant threat in the form of mutation in the immediate ecosystem. Either way, the membrane that separates the body from the virus is threatened and made vulnerable. The intricate nature and the viral and invisible unconscious of the Anthropocene is evidence enough of the interpenetration between the human body and the supplement contagion. We think virally, through strategies of espionage and sabotage, implantation and manipulation, death by substitution [expendability] and not an absolute death [an absolute death makes the body redundant and fails to economize it and conversely to subsume it back into the economy]. Cobb in Christopher Nolan's Inception $^{11}$ says, "An idea is like a virus, resilient, highly contagious. The smallest seed of an idea can grow. It can grow to define or destroy you" (Inception): Transplantation. More and more bodies are left for the donation of vital organs, reused instead of decomposed. The body is a matter, essential matter, and is not left to waste. 
The contagion is pure trace and therefore has a non-identical point of origin. It is an original trace. In The Problem of Genesis in Husserl's Philosophy Derrida underlines this original absence of an origin of the contamination and its essentially differential nature:

In fact, the question that governs the whole trajectory is already: 'How can the originality of a foundation be an a priori synthesis? How can everything start with a complication?' All the limits on which phenomenological discourse is constructed are examined from the standpoint of the fatal necessity of a 'contamination' [...] the quaking of each border coming to propagate itself onto all the others. A law of differential contamination imposes its logic from one end of the book to the other, and I ask myself why the very word 'contamination' has not stopped imposing itself on me from thence forward (Husserl xv)

A spokesperson from Beijing reiterated the misappropriation leading on to a vacant blame game that had erupted globally directed at China which was the original epicenter of the 2020 COVID-19 contagion. Confirming that although Wuhan was the place the virus was first detected, it cannot be affirmed as the original breeding ground or place of invention of the virus Ji Rong, a spokesperson for the Chinese Embassy pointed out clearly that, "China has neither created the virus nor intentionally transmitted it. The [name] so-called 'Chinese virus' is absolutely wrong" (Business). Scientists in the United States have also claimed that like its previous version SARS, this novel strain actually disseminates either from infected bats or from cross infections involving bats and other animals that are consumed in large numbers all over China. Irrespective of whether the SARS-CoV-2 was manufactured as a biological weapon, transmitted from cross infected animals or released from melting glaciers [which remains true for many contagions], its true origin remains in a condition of multiplicity and is therefore always in a constant state of différance. The pure origin, provided there was such a case [because of the possibility of over-determination or over-coding] is replaced by a series of virtual traces that refer to each other infinitely without end. This originary absence as stated earlier is what characterizes the viral contagion, and therefore its circulation and infection is not only pathological but psychological [it conquers all aspects of human life without end] and even epochal to the extent of requiring ontological revisionism.

We can sum up our study of this virological ontology up till now with two clearly demarcated theses:

Thesis 1: The virus is pure trace. It has no originary presence i.e. its origin is a multiplicity, and Thesis 2: The coming of the Anthropocene converges with the emergence of this virological study of being.

Let us now revert to the reception of the virus in the global sphere and within the limits of the anthropogenic world. In Plato's Pharmacy, a text included in his book Dissemination, Jacques Derrida retells the story of the 'pharmakon ${ }^{12 '}$ from Plato's Phaedrus.

Theuth came to him [Ammon] and exhibited his arts and declared that they ought to be imparted to the other Egyptians ... when it came to writing, Theuth said, "This discipline (to mathema), my King, will make the Egyptians wiser and will improve their memories (sophōterous kai mnèmonikōterous): my invention is a recipe (pharmakon) for both memory and wisdom." But the King said... etc. $(274 c-e)$.

Let us cut the King off here. He is faced with the pharmakon. His reply will be incisive (Plato 78)

Derrida breaks off from Plato's text here to put into critical scrutiny the invention of the pharmakon. He talks about Logos [the law of the father, or in our case, the law of presence, the presence of the body], truth [alètheia], persuasion [peithō], art [tekhnē] and the opposition between the king Ammun and the scientist inventor Theuth, emphasizing the former's distrust of the latter, but in his analysis, Derrida excludes the 
presence of that very thing he discusses, from the relationship between Theuth and Ammun. He excludes the presence of politics, or more precisely the presence [or the possibility of the presence] of a pact, a negotiation between the two figures. Derrida excludes the possibility of contamination between the bodies of the two Gods. But going back to Derrida's critique, he identifies Ammun as the responsible father of the Logos or self-presence, who is keen and incisive about preserving the purity of memory, recollection, and speech, from the dangerous supplement that Theuth presents him with. Ammun rejects the pharmakon on the basis of its lack of substance, calling it only a "semblance to wisdom" (102) claiming that, "this invention will produce forgetfulness in the souls of those who have learned it because they will not need to exercise their memories." (102) Wary of the contagion, the Father protects the Logos and Civilization from external threats and refuses to go into any kind of negotiations. The Father of the Anthropocene stands a different ground [a bottomless ground].

Unlike the Egyptian Father of Logos, the Father of the Anthropocene is not a stout preserver of the convention, but is the betrayer of Law for the sake of political power, putting at stake the whole essence of humanity. Derrida in The Specters of Marx likens the political administrator of the Anthropocene to the Timon of Athens, who calls for a certain fidelity to infidelity:

Addressing himself to prostitution or to the cult of money, to fetishism or to idolatry itself, Timon trusts. He gives faith, he believes, he indeed wants to credit ("I'll trust") but only in the imprecation of a paradoxical hyperbole: he himself pretends to trust in that which. from the depths of abjuration. from the depths of that which is not even capable or worthy of an oath ("you are not oathable") remains nevertheless faithful to a natural instinct, as if there were a pledge of instinct, a fidelity to itself of instinctual nature. an oath of living nature before the oath of convention, society, or law. And it is the fidelity to infidelity, the constancy in perjury (Specter 55)

The God of the Anthropocene is politically apolitical. He seeks out poisonous inventions to unleash upon the world in order to fulfill his mad ambitions, not knowing completely the nature and hence the possible consequences of the inventions he embraces. There is, therefore, a change of attitude in the reception of the contagion: from Ammun's rejection [and therefore preservation] to Timon's willful embrace [and hence contamination and destruction]. In Alan Moore's Watchmen, it is Adrian Veidt (Ozymandias) who uses Dr. Manhattan [a theoretical physicist turned superhero] to reduplicate his power signature into energy reactors, out of political ambition. He is successful in wiping out entire cities with the help of the reactors, the trail of which takes us back to the real Manhattan Project conducted by the US President Harry Truman with the help of Physicist J. R. Oppenheimer known as the father of the atomic bomb. The project had finally led to the bombings of Hiroshima and Nagasaki in 1945 and gave the United States an absolute hegemony in the production of nuclear energy for the next few decades. The mythic structure of the relationship between the king and the inventor is therefore reversed from being one based on suspicion and skepticism, to one that is grounded on alliance and conjunction for the sake of politics, power, and eventually, destruction. Oppenheimer had later stated that the destructive potential of the Manhattan Project had reminded him of words from the Bhagvad Gita: "Now I have become Death, the destroyer of worlds ${ }^{13 "}$ (Hijiya)

Ironically it the United States who has ended up suffering the worst in comparison to Asian Superpowers such as China or Japan, when it has come to pandemics over the last century or so, even though many of those pandemics had originated in Asian states. Several other instances reinforce the mutation of the initial monarch-scientist or the king-inventor myth, which has also added a new dimension to the contagion: the reaction and response of the victim populace. In Satyajit Ray's 1980 film Kingdom of Diamonds [Hirak Rajar Deshe], the tyrant Raja (King) of Hirak in conjunction with his court scientist, who invents a brainwashing device called the jantarmantar, deploys it on the people of the land, especially the 
rebels who protest his rule. The machine is able to (ideologically) lobotomize the rebels until the very end, when the insurgence goes beyond the monarch's administrative control and the machine is ended up being used on the Raja and his scientist themselves. Again in Shakespeare's another play The Tempest the figure of the King/Monarch and the Scientist/Inventor merges into the figure of the magician Prospero, who finally reconciles with his fate when he accepts his role as the Duke of Milan [a role which he had previously relinquished], enchanting his way into political power with the use of magical spells on the other characters in the play.

With the reversal of the archetypal King's attitude towards the pharmakon/magic/invention, the contagion is unleashed over the subject population, resulting in panic, hostility, and eventually, chaos. The reception of the contagion, therefore, is highly ambiguous [in fact more caustic than profitable] when taken in terms of the reaction or the effect it produces upon the body politic as a whole. But when considered with respect to non-anthropological factors such as the environment and the general health and economy of the ecosystem the pharmakon has more favorable conduct, although not every time [the human population has an inverse relationship to the population of many animal species because of poaching, hunting, and commercialization, thus although an atomic bomb has an equally adverse effect on both, contagions that target human bodies favor other forms of life]. Much like the origin of the virus which is always multiple, the consequence of the virus remains a heterogeneous multiplicity. The infection in the form of a pandemic or an epidemic can result in a radical shift of economic status quo, political structures, and even in a country's military strength of working-class population [which again indirectly affects the economy]. This takes us to the third thesis of our study.

Thesis 3: The effect of the pharmakon/virus/contagion is geopolitically unpredictable, much like its intention remains undecipherable.

The overwhelming load of a virus or contagion is unquestionably immense, and to the extent that it short circuits the general ontology of the body as presence or self-presence. But the metaphor of contamination doesn't only present itself at the level of the body/contagion dialectic but extends to the very idea of the dialectic itself. Derrida substitutes [and contaminates] the dialectic itself, with the active trope of the virus. As Peta Mitchell notes in her essay Contagion, Virology, autoimmunity: Derrida's rhetoric of contamination:

In Derrida's early work on Husserl and phenomenology, contamination stands in for or takes the space of a word Derrida states he 'had to give up', namely dialectic. As a concept, dialectic cannot adequately address or express the interpenetrating relationship between inside and outside, the failure to keep the origin 'pure' form that which would contaminate it (Mitchell 79)

Contamination or the possibility of contamination is the only possible state of the dividing line between the dialectic [in this case the body/contagion dialectic]. The dialectic is always and has always been threatened by this dubious invention of Thamus. Yet, as stated earlier, the success of the contagion rests on the body that receives it, or more precisely the attitude of the body which is presented with the contagion. The contagion is a modern malady of progress [the supplement] which the traditionalist is suspicious of and the democratic ruler readily accepts [we could here stress a little upon the differential relationship of the Freudian Eros and the death drive ${ }^{14}$; the latter as a different form of the former deferred; similarly the modernist as an evolved form of the traditionalist]. Derrida's metaphysics or neometaphysics rests on a double deployment of this metaphor of contamination. The contagion contaminates the dialectic, structurally deconstructing the Hegelian metaphysical model of the inside and the outside, subsequently allowing the contagion to infect the whole system that has been begotten by Plato. Derrida is the modern father, the ruler of the contagion, but he is also the God of the Logos to the extent that the virus substitutes the Logos and takes its place at a center, and wrecks havoc on it, breaking 
it down, making it multiple, exposing in the process Derrida's own inadequate reading of Plato's text and his need to simultaneously separate Ammun the King of Logos from Thamus the inventor of the pharmakon before uniting them once again ["If reading and writing are one...if reading is writing, this oneness designates neither undifferentiated (con)fusion nor identity at perfect rest; the is that couples reading with writing must rip apart" (Plato 67)], instead of using their union as a presupposition [Derrida undermines the mythic structure of the pharmakon episode in Phaedrus].

Emphasizing on this movement of the double deployment of the virus let me finally come around to the difference [if there is any at all] between Virology and the Anthropocene. Although difficult, a provisional relationship can be established: whereas the virus moves through contact [hence metonymically], the Anthropocene is the general name assigned to a geological period through replacement [and therefore metaphorization]. The virological movement into the body thereby can be assigned a historical moment(s) i.e. the contagion can be historicized through the presence of the disease [influenza causing the flu, the SARS-CoV-2 causing Covid-19 or the plague being caused by the bacterium Yersinia pestis]. The Anthropocene, however, doesn't move through contiguity, but only by 'supplantation'. Both follow the law of the supplement, but on different orders, on different levels and dimensions. The virus is micrological and takes us towards the Anthropocene which is micrological, their relationship, therefore, being one of différance. The virus is thereby the deferred presence of the Anthropocene; it anticipates and participates in the coming of the viral age, without presenting it as such [in fact such a presentation would be impossible because the Anthropocene would be the age of absence and trace]. The virus as an idea that sticks, not only with regard to the information it seeks to proliferate but doubly so, because it carries along with it the idea of virology itself, making transmission impossible without infection. Finally, hence, a fourth thesis can be presented here at this moment of the essay.

Thesis 4: the virus [the virological movement] is the deferred presence of the Anthropocene [this is also a reworking of the second thesis].

Plato's [Theuth's] pharmakon might have been one of the first active presences of the study of the virus in anthropological discourse, putting at stake the speech, body, memory, and self-presence of Man, but a study that only appeared to express caution and vigilance towards the threat which the contagion was thought to present. Yet the caution was only a false skepticism on the part of the God of Logos, who, concealing an underlying lust and even a hidden kinship with the pharmakon, led Man into believing his commitment to knowledge and convention [a knowledge that was always already corrupt]. The modern pandemic and the alarming rate of panic it is and has been able to engender in the mind of the social individual is nothing more but an indication of the latter's increased awareness [virological and ideological] of an impending condition, pointing to the culmination of centuries of infection and political corruption at the center(s) of power and knowledge [and conversely a corruption that was always already there since the birth of the Logos]. To the extent that the virological age is the realization of the epoch of anthropological agency, that is of Man's corruption of the natural state [a state] which was always already corrupt, to begin with, the Anthropocene is not the coming of Man but a return of Man to his initial state: as a virus or an infection. The Anthropocene [or the virological era] is hence the lifting of all imaginary veils, between the body and the contagion, with one becoming the other [the body as the virus and the virus as the body] till no separation remains possible, inaugurating an age of the virus that shows minimal restraint, forever participating in an infinite movement of infection and play.

\section{End Notes:}

1. SARS-CoV-2 is the name of the virus and not the disease. the disease caused by this virus is the Covid-19. 
2. This ontology is not an ontology in the traditional sense of the term. Virology is both an ontology and a critique [through contamination] of ontology [and being itself]. It strives to infect the very idea of what an ontology entails: body, being, presence and substance.

3. The era of the anthropos i.e. Man. Considered to be a reference to the current geological epoch that has seen Man and Civilization subsume and control every aspect of the Earth's resources, from climate and energy to other life forms. The Anthropocene is thought to be succeeding the age of the Holocene.

4. According to Merriam-Webster Virology refers to the study of viruses and virus like submicroscopic parasites or viral agents. Jacques Derrida takes us virology as a metaphor or an analogy to radicalize and critique the Western Metaphysics of Presence.

5. A transcendental phenomenologist who thought that transcendental presence or consciousness sets the boundaries for all kinds of experience.

6. All these Derridean undecidables, along with the likes of différance, hymen or contagion belong to a signifying chain of non-synonymous substitutions.

7. Indicating a radical event in history: "What would this event be then? Its exterior form would be that of a rupture and a redoubling" (Structure 351)

8. This new metaphysics [which is also a critique of metaphysics] includes ideas of infection, virology, sabotage and parasitism.

9. Derrida is challenging the presence, solidity and integrity of this dividing line, implying that it is constructed rather than real. He tries to dismantle the inviolability of the dividing line with the trooe of the virus.

10. The concept of autoimmunity appears first in Derrida's explicitly political writings, which, after 9/11, have become thoroughly entangled with the problematics of "terror." In Autoimmunity: Real and Symbolic Suicides, he defines the autoimmunitary processes of democracy as follows: "As we know, an autoimmunitary process is that strange behavior where a living being, in quasi-suicidal fashion, 'itself' works to destroy its own protection, to immunize itself against its 'own' immunity" (Immune). Auto-immunology or autoimnunity belongs to Derrida's chain of non-synonymous substitutions [at the far end of the signifying chain].

11. Nolan's film centers on espionage agencies that steal [or plant] secrets [and ideas] from human minds.

12. Derrida says that the pharmakon is both remedy and poison, and therefore is an undecidable trace term without a predefined meaning.

13. A misquotation from The Bhagavad Gita [Sir Edwin Arnold's translation],"Thou seest Me as Time who kills, Time who brings all to doom"

14. In his essay Différance, Jacques Derrida finds an underlying continuity in Sigmund Freud's topology of the mind. Instead of thinking about the conventional way of the id, the ego and the super-ego as different parts of the human mind, Derrida establishes a relationship based on différance i.e. each term as the other term differed and deferred. The Democratic Father of the pharmakon is nothing but a different and deferred presence of the Father of Logos.

\section{References}

[1]. China neither created nor transmitted deadly coronavirus intentionally, says Embassy Spokesperson Ji Rong (2020, March 26). Business Times. n. pag.

[2]. Derrida, Jacques. Plato's Pharmacy. Dissemination. Trans. Barbara Johnson. New York: Bloomsbury Academic, 2016. Print.

[3]. Structure, Sign and Play in the Discourse of the Human Sciences. Writing and Difference. Trans. Alan Bass. New York: Routledge Classics, 2001. Print.

[4]. Specters of Marx. Trans. Peggy Camuf. New Yok: Routledge Classics, 2006. Print. 
[5]. Voice and Phenomenon: Introduction to the Problem of the Sign in Husserl's Phenomenology. Trans. Leonard Lawlor. Evanston, IL: Northwestern University Press, 2011. Print.

[6]. Hijiya, James A, ed. "The Gita of Robert Oppenheimer, (June 2000) Proceedings of the American Philosophical Society." Philadelphia: n.p., 26 November 2013. Print.

[7]. Howells, Christina. Deconstruction from Phenomenology to Ethics. Cambridge: Polity, 1999. Print.

[8]. Inception. Dir. Christopher Nolan. Perf. Leonardo DiCaprio, Michael Caine, Joseph GordonLevitt and Marion Cotillard. Syncopy, 2010. Film.

[9]. Mitchell, Peta. "Contagion, virology, autoimmunity: Derrida's rhetoric of contamination." Parallax vol. 23(1), 2017, pp. 77-93. Print. 